Portland State University

PDXScholar

\title{
How Well has Land-Use Planning Worked Under Different Governance Regimes? A Case Study in the Portland, OR-Vancouver, WA Metropolitan Area, USA
}

Jeffrey D. Kline

USDA Forest Service

Paul R. Thiers

Washington State University - Vancouver, pthiers@vancouver.wsu.edu

Connie P. Ozawa

Portland State University, ozawac@pdx.edu

J. Alan Yeakley

Portland State University, yeakley@pdx.edu

Sean N. Gordon

Portland State University

Follow this and additional works at: https://pdxscholar.library.pdx.edu/usp_fac

Part of the Urban Studies Commons, and the Urban Studies and Planning Commons Let us know how access to this document benefits you.

\section{Citation Details}

Kline, J. D., Thiers, P., Ozawa, C. P., Alan Yeakley, J. J., \& Gordon, S. N. (2014). How well has land-use planning worked under different governance regimes? A case study in the Portland, OR-Vancouver, WA metropolitan area, USA. Landscape \& Urban Planning, 13151-63.

This Article is brought to you for free and open access. It has been accepted for inclusion in Urban Studies and Planning Faculty Publications and Presentations by an authorized administrator of PDXScholar. Please contact us if we can make this document more accessible: pdxscholar@pdx.edu. 
Research Paper

\title{
How well has land-use planning worked under different governance regimes? A case study in the Portland, OR-Vancouver, WA metropolitan area, USA
}

\author{
Jeffrey D. Kline ${ }^{\mathrm{a}, *}$, Paul Thiers ${ }^{\mathrm{b}}$, Connie P. Ozawa ${ }^{\mathrm{c}}$, J. Alan Yeakley ${ }^{\mathrm{d}}$, Sean N. Gordon ${ }^{\mathrm{e}}$ \\ a USDA Forest Service, Pacific Northwest Research Station, 3200 SW Jefferson Way, Corvallis, OR 97330, United States \\ b School of Politics, Philosophy and Public Affairs, Washington State University, Vancouver, WA 98686, United States \\ ${ }^{\mathrm{c}}$ Toulan School of Urban Studies and Planning, Portland State University, Portland, OR 97201, United States \\ d School of the Environment, Portland State University, Portland, OR 97201, United States \\ e Institute for Sustainable Solutions, Portland State University, Portland, OR 97201, United States
}

\section{H I G H L I G H T S}

- We examine urban growth boundary effectiveness at conserving farm and forest land in Portland, OR-Vancouver, WA (USA).

- We focus on forest, farm, and developed land uses from the mid-1970s to the mid-2000s.

- We found that urban growth boundaries have effectively contained low-density residential and urban development.

- These effects have varied among counties and between the Oregon and Washington portions of the metropolitan area.

- Differences in effectiveness likely owe in part to each jurisdiction's unique geography and land use planning history.

\section{A R T I C L E I N F O}

\section{Article history:}

Received 26 March 2014

Received in revised form 22 July 2014

Accepted 23 July 2014

Available online 28 August 2014

\section{Keywords:}

Sustainable development

Growth control

Urban sprawl

Oregon land use planning

Zoning

\begin{abstract}
A B S T R A C T
We examine land use planning outcomes over a 30-year period in the Portland, OR-Vancouver, WA (USA) metropolitan area. The four-county study region enables comparisons between three Oregon counties subject to Oregon's 1973 Land Use Act (Senate Bill 100) and Clark County, WA which implemented land use planning under Washington's 1990 Growth Management Act. We describe county-level historical land uses from the mid-1970s to the mid-2000s, including low-density residential and urban development, both outside and inside of current urban growth boundaries. We use difference-in-differences models to test whether differences in the proportions of developed land resulting from implementation of urban growth boundaries are statistically significant and whether they vary between Oregon and Washington. Our results suggest that land use planning and urban growth boundaries now mandated both in Oregon and Washington portions of the study area have had a measurable and statistically significant effect in containing development and conserving forest and agricultural lands in the Portland-Vancouver metropolitan area. Our results also suggest, however, that these effects differ across the four study-area counties, likely owing in part to differences in counties' initial levels of development, distinctly different land use planning histories, and how restrictive their urban growth boundaries were drawn.
\end{abstract}

Published by Elsevier B.V.

\section{Introduction}

An enduring land-use policy question is how best to conserve forest and agricultural lands both as a basis for productive

\footnotetext{
* Corresponding author. Tel.: +1 5417587776 .

E-mail addresses: JKline@fs.fed.us (J.D. Kline), PThiers@vancouver.wsu.edu (P. Thiers), OzawaC@pdx.edu (C.P. Ozawa), Yeakley@pdx.edu (J. Alan Yeakley), Sean.Gordon@pdx.edu (S.N. Gordon).
}

industries and for their contribution to peoples' quality of life (e.g., Sorensen et al., 1997; Stein et al., 2005). Recent interest has extended to include addressing the social and environmental costs of urban sprawl often associated with forest and agricultural land loss (Bengston, Fletcher, \& Nelson, 2004). These policy questions are central to an emerging research framework that seeks to understand both how humans might manage landscapes sustainably and how landscapes shape human communities, by examining metropolitan areas as coupled human-natural systems characterized by dynamic and interacting socioeconomic and ecological 
agents, conditions, and processes (e.g., Collins et al., 2011). The roles that local and state governance and policies play in conserving forest and agricultural lands and preventing urban sprawl are of particular interest. Land-use policies can greatly influence urban and suburban landscapes, and the people who live in them who in turn shape land-use policy as voting citizens. Evaluating the effectiveness of land-use policies in urbanizing areas during periods of high growth can indicate how resilient socioeconomic and ecological systems might be to stressors, such as human settlement and climate change. These interests influenced our investigation of land-use policy effects in the Portland, OR-Vancouver, WA (USA) metropolitan area, which has developed over the past 30 years under contrasting governance regimes at state, regional and local levels.

Straddling the Oregon-Washington border defined by the Columbia River, the Oregon side of the Portland-Vancouver metropolitan area has been subject to Oregon's land-use planning law since 1973. Among regulatory approaches, Oregon's statewide land-use planning program and its mandated establishment of urban growth boundaries is an often cited example of success (e.g., Abbott, Howe, \& Adler, 1994; Gustafson, Daniels, \& Shirack, 1982; Harvey \& Works, 2002). In comparison, the Washington portion of the Portland-Vancouver metropolitan area did not fall under state mandated urban growth regulation until 1990, although it had begun locally addressing urban growth earlier. The juxtaposition of differing land-use planning histories played out within this single metropolitan area provides a "natural experiment" for considering the influence of planning on forest and agricultural land conservation, and urban sprawl. Few studies have rigorously examined land-use planning effectiveness at conserving forest and agricultural lands and containing urban growth (Gosnell, Kline, Chrosteg, \& Duncan, 2010). A difficulty is separating the effects of planning from other influential factors, including population growth, location, and topography (Kline, 2000). Evaluating planning effects also is complicated by the evolving nature of land-use planning programs as they are adjusted to correct perceived problems (Gosnell et al., 2010). This evolution can make it difficult for researchers to link programmatic changes to observed changes in land use and development.

For example, many studies of Oregon land-use planning effects have examined regional land-use trends using data from the US Census of Agriculture and other sources (e.g., Daniels \& Nelson, 1986; Furuseth, 1981; Nelson, 1992) or developed regional and statewide indicators of land conservation and development (e.g., Jun, 2004; Nelson \& Moore, 1996; Nelson, 1999). Although these studies provide useful snapshots of ongoing change under landuse planning, it is difficult to conclude what influence planning had in bringing about land-use outcomes (Gosnell et al., 2010). Other studies have evaluated land-use planning effects using econometric models to control for commuting proximity, city size, and topographic features and other factors (Jun, 2004; Kline \& Alig, 1999; Kline, 2005), but results have been mixed. Gosnell et al. (2010) have suggested a need for greater spatial tracking and evaluation of forest and agricultural land lost to development, both inside and outside urban growth boundaries (p. 190). Dempsey and Plantinga (2013) initiated such inquiry using fine-scaled land-use data from satellite imagery and difference-in-differences econometric models to examine the influence that urban growth boundaries have had on containing development in select Oregon cities.

We build on this work by using aerial photography-derived land-use data to examine low-density residential and urban development outcomes over a 30-year span, with a focus on comparing the four counties (Clackamas, Multnomah, and Washington counties, OR, and Clark, WA) comprising the Portland-Vancouver metropolitan area, under contrasting land-use planning regimes. Our objective was to (1) determine whether urban growth boundaries have been effective at containing low-density and urban development and conserving forest and agricultural (or "resource") lands; and (2) determine whether effects have varied between Oregon and Washington. We investigated county-level changes in the proportions of low-density residential and urban land from the mid-1970s to the mid-2000s, examined changes both outside and inside current urban growth boundaries, and used difference-in-differences regression models to test whether incremental differences in developed land proportions among counties are statistically significant. We also computed development containment measures that enable county-by-county comparisons of the degree to which low-density and urban development has been contained and resource lands conserved within each county. Our research is a foundational component of the Portland-Vancouver ULTRA-Ex (Urban Long-term Research Area) project which examines how people can sustainably manage urbanizing landscapes, by comparing two adjacent cities, their associated urbanizing regions, and contrasting land-use policies and social contexts.

\section{Growth control in the Portland-Vancouver metropolitan area}

Contemporary land-use planning began in the PortlandVancouver metropolitan area with creation of Oregon's statewide land-use planning program. Enacted in 1973, the Oregon Land Use Act (also known as Senate Bill 100) was a response to rapid population growth and development of forest and agricultural lands in western Oregon during the 1950s and 1960s. Existing legislation had already authorized local governments to manage urban growth; however, residential development of forests and agricultural lands outside of incorporated cities often remained unplanned and unregulated (Gustafson et al., 1982). The Oregon Land Use Act required all cities and counties to prepare comprehensive land-use plans consistent with 15 (and later 19) statewide goals and to provide for the orderly and efficient transition of rural lands to urban uses and to conserve forest and agricultural lands. Goal 14 required cities and counties to contain new development inside of "urban growth boundaries," intended to accommodate growth over a 20 -year period. Development was to be significantly reduced outside urban growth boundaries. Lands zoned for exclusive agricultural or forest use, based on soil types and topography, were expected to be mostly off limits for development (Pease, 1994). Lands already physically or irrevocably committed to nonagricultural or non-forest uses, or lands deemed inappropriate for non-urban use, were designated as "exception areas" where development could be allowed pending approval by local authorities. A new state authority, the Land Conservation and Development Commission, was established to oversee the program, staffed by a new Department of Land Conservation and Development (Knaap \& Nelson, 1992). By 1986, land-use plans had been substantially approved by the Land Conservation and Development Commission for all of Oregon's 36 counties and 241 cities (Knaap, 1994).

Oregon's statewide planning program meant several changes for the three counties that comprise the Oregon portion of the Portland-Vancouver metropolitan area. Comprehensive plans were acknowledged by the Land Conservation and Development Commission, in whole or in part, for Multnomah County in 1980, Clackamas County in 1981, and Washington County in 1983. The City of Portland's own plan was acknowledged in 1981. A new agency-Portland Metro-was established in 1979 to coordinate regional land use, growth management, and transportation planning, and to manage the region's urban growth boundary (Seltzer, 2004). Portland Metro's influence generally has been exerted through the creation of "functional plans" that address regional issues, such as transportation and open space acquisition. Although 
county and city comprehensive plans "are the primary legal documents guiding all local planning and development decisions," Metro can require that plans be revised for consistency with regional functional plans (Seltzer, 2004).

Most importantly, Metro holds the legal authority for establishing and managing urban growth boundary expansions for the Oregon portion of the region, including 25 cities located across portions of three counties. Metro administers this authority collaboratively with significant input from the public, property owners, cities, and counties, with the state's Land Use Board of Appeals serving as the final arbitrator (Rosan, 2007). A notable element of the system is the identification of "exception areas," which encompass lands that for various reasons hold little resource value, lie outside the urban growth boundary, and on which limited development may be allowed. This system of oversight authority has resulted in fewer than a dozen urban growth boundary expansions totaling about 11,000 ha, with one 2002 decision accounting for nearly half (4860 ha) of the area increase, mostly in Washington and Clackamas Counties (Ozawa, 2012).

State-level growth management policies were adopted 17 years later in the Vancouver, WA portion of the metropolitan area. Planning in Washington State before that had been local in scope (Settle \& Gavigan, 1993). By 1990, rapid population growth and congestion in the Puget Sound region led to passage of the Growth Management Act to provide greater state guidance to planning and growth control. Amended in 1991, the Act required counties with greater than 50,000 people and $10 \%$ or more 10 -year growth rate to develop comprehensive plans in cooperation with their largest cities (Settle \& Gavigan, 1993). The Act called for establishing urban growth boundaries sufficient to accommodate 20 -years projected growth. Regional growth management hearing boards were created to provide limited state oversight of county and city planning. Viewed as a more decentralized approach than Oregon's, Washington's Growth Management Act mostly left local governments free to develop and enforce growth management plans and policies. Plans and urban growth boundaries adopted by counties and cities were presumed to be compliant unless formally petitioned, giving local officials significant leeway in how they might comply with the Act's requirements (Settle \& Gavigan, 1993).

Clark County, WA, where the City of Vancouver is located, first passed a comprehensive growth management plan in 1979 (Clark County, 2010), well before Washington's Growth Management Act. Although this early plan did not define formal urban growth boundaries, it did distinguish lands suitable for "urban intensity housing, commercial and industrial development" from rural lands. Refinements in 1980 defined specific zoning districts for forest, agricultural, and other rural land uses, as well as suburban and urban development (Clark County, 2010). Following state passage of the Growth Management Act in 1990, Clark County engaged in a contentious comprehensive planning process, establishing the first formal urban growth boundary in 1994. Substantial expansions of the urban growth boundary have occurred in 1997, 2004 and 2007 (Clark County, 2010). Although Clark County's land-use history often is viewed as having been less restrictive than that of neighboring Oregon counties (e.g., Walker, 2011), to our knowledge no studies have formally compared the relative influence of these two planning efforts on land-use outcomes in the region.

\section{Methods}

We examined land-use changes within counties comprising the Portland-Vancouver metropolitan area between the observation period 1974-1976, near the time that Oregon's land-use planning program was enacted, and 2005-2006, the most recent time for which land-use data are available for each of the
Oregon and Washington counties. Although it is notably difficult to associate individual land-use planning programmatic changes to specific changes in land-use trends (e.g., Gosnell et al., 2010), we can document the effects of separate planning histories based on landuse outcomes. Because urban growth boundaries have expanded several times during the study period, we assumed that current boundaries define the preferred development outcomes for each county. Our analysis examined the degree to which actual development outcomes resulting from the land-use planning histories of individual counties are consistent with preferred outcomes represented by current urban growth boundaries. We assumed that if urban growth boundaries have been successful, we would find that: (1) lands inside urban growth boundaries would have become more urban, (2) forest and agricultural lands outside urban growth boundaries would have remained fairly constant, and (3) lowdensity development would be fairly limited everywhere.

\subsection{Study area}

The four counties comprising the Portland, OR-Vancouver, WA metropolitan area (Fig. 1) all experienced significant population growth during the study period. The counties had a combined population of nearly 2.1 million people in 2010 . Three Oregon counties located south of the Columbia River in Oregon-Clackamas, Multnomah, and Washington-include the City of Portland and are subject to Oregon's land-use planning program and Metro. Population growth from 1970 to 2010 in these counties was $126 \%$ (Clackamas County), 32\% (Multnomah County), and 235\% (Washington County) (US Department of Commerce, Census Bureau, 2013). This growth increased population density from a combined 112 persons per square kilometer in 1970 to 209 persons per square kilometer in 2010-34-78 persons per square kilometer in Clackamas County, 498-658 persons per square kilometer in Multnomah County, and 84-282 persons per square kilometer in Washington County (US Department of Commerce, Census Bureau, 2013). As the fourth metropolitan area county, Clark County, WA is located north of the Columbia River, includes the City of Vancouver, and is subject to Washington's land-use planning program. Clark County experienced a sizable share of the region's 1970-2010 population growth, growing $231 \%$ and increasing its population density from 79 to 261 persons per square kilometer. Although population has grown throughout the metropolitan area, population growth rates were highest in Washington County and Clark County, where population densities were the lowest at the beginning of the study period.

\subsection{Data}

Historical land-use data spanning 1974-2009 for Oregon and 1976-2006 for Washington were compiled by the Oregon Department of Forestry and USDA Forest Service's Forest Inventory and Analysis Program, Pacific Northwest Research Station (Gray et al., 2013; Lettman, 2011, 2013). The data consist of geo-referenced point observations of discrete land-use classes observed on nonfederal lands from photo-interpretation of a systematic-random grid of points located on aerial photographs for 1974, 1984, 1994, 2000, 2005, and 2009 in Oregon, and 1976, 1994, and 2006 for Washington, at a sampling density of one point per 187 ha (e.g., Gray et al., 2013). Land-use classes include wildland forest, mixed forest-agriculture, intensive agriculture, low-density residential, and urban (Fig. 2). The data enable comparisons of land-use changes occurring on non-federal lands between counties and states, and outside and inside urban growth boundaries over a roughly 30year period. Our analysis necessarily omits federal lands, in part because similar data for federal lands in the study region do not exist. However, because federal lands in the study region mostly 


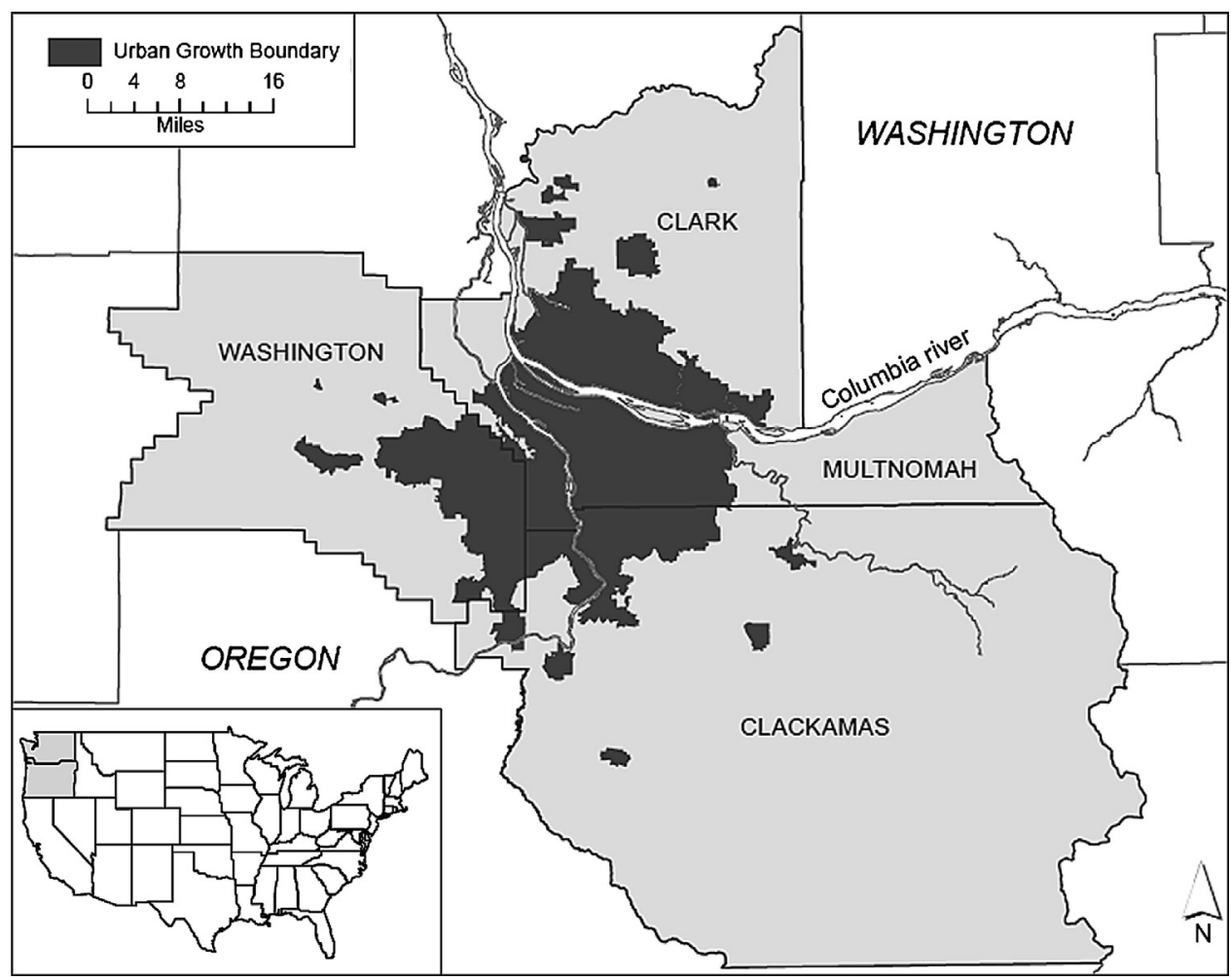

Fig. 1. Four-county Portland, OR-Vancouver, WA metropolitan area showing current (2011) urban growth boundaries.

consist of national forest land, their omission from our analysis is of little consequence.

The data define urban uses as land of at least 16 ha and comprised of commercial, service, or subdivided residential uses with city street patterns and closely spaced buildings (Lettman, 2011). The data define low-density residential uses as land of any parcel size in rural residential or low-density commercial uses, and with nine or more structures per $2.59 \mathrm{~km}^{2}$ not used for agriculture or forestry (Lettman, 2011). The lower bound structure density defines low-density residential uses more in a rural context than a suburban or semi-urban context. This is consistent with a primary goal of Oregon land-use planning of conserving forest and farmland (e.g., Lettman, 2011). The Land Conservation and Development Commission has considered $2-4$ ha residential lots as a form of rural residential zoning, and such densities have been allowed outside urban growth boundaries, when in exception areas or on agricultural lands of poor soil quality, for example. The data indicate that low-density lands average about 1 structure per 1.4 ha, and structure density for many observations exceeds that. We focused our analysis on the 1974-1976 and 2005-2006 observations from each state.

Geo-referencing enabled us to combine the land-use data with digital maps of urban growth boundaries, regional road networks, slope, and elevation to develop explanatory variables for regression analysis. These additional data were available from the Oregon Geospatial Enterprise Office. The "current" urban growth boundary map used for the analysis describes urban growth boundaries as they existed 2011, which was the most recent available at the time of analysis. Slope and elevation data were developed using the Oregon digital elevation model at a $30-\mathrm{m}$ resolution.
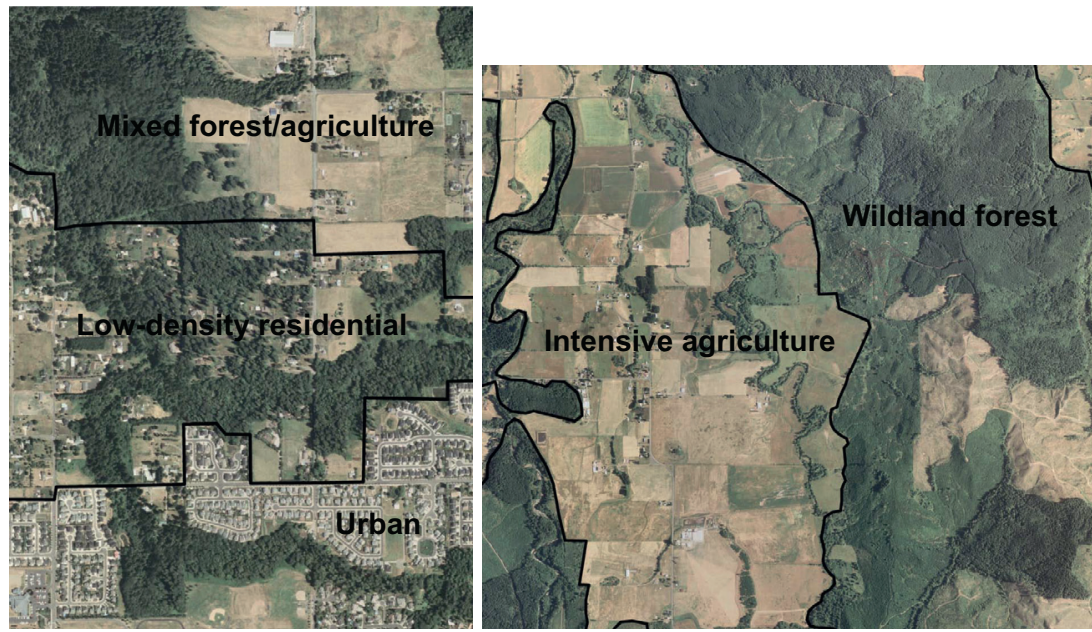

Fig. 2. Example depictions of land use classes from aerial photography, used with permission from Gray et al. (2013). 


\subsection{Empirical analysis}

We began our analysis by first tabulating the proportion of land in different uses for each of the four metropolitan area counties for 1974-1976 and 2005-2006, enabling comparisons among counties, and between the Oregon counties and Clark County, WA. Second, we combined our geo-referenced point observations of land use with maps of current urban growth boundaries in the Portland-Vancouver metropolitan area using ArcGIS to identify observations as either outside or inside urban growth boundaries. This enabled county comparisons of the proportions of low-density versus urban development, outside and inside urban growth boundaries. We included "exception area" lands in Oregon counties along with lands located inside urban growth boundaries. Exception areas typically permit new development on rural residential lots of about 2-8 ha or on smaller lots if they predate establishment of urban growth boundaries. Development at these densities is notably higher than would be allowed elsewhere outside urban growth boundaries. Third, we estimated "difference-in-differences" models to examine whether changes in the proportions of developed land (lowdensity or urban combined) among counties for the 1974-1976 and 2005-2006 observations are statistically significant. Fourth, we used difference-in-differences model estimated coefficients to compute development containment measures to compare the degree to which counties contained development within urban growth boundaries and conserved resource lands over the 30 -years examined.

The difference-in-differences estimator is a form of regression model that is useful for evaluating policy effects using crosssectional data gathered both before and after polices have been implemented (Wooldridge, 2006). Its use for evaluating land-use planning effects has been demonstrated by Dempsey and Plantinga (2013). An advantage of the difference-in-differences model structure is that it controls for the potential effects of time-varying factors, such as population growth rates and densities, by isolating these potential effects using an explanatory variable representing time (Dempsey \& Plantinga, 2013). This is necessary because while population growth rates and densities undoubtedly influence development and the application of land use planning policies (e.g., location of urban growth boundaries), land use planning policies themselves influence population growth rates and resulting densities. In our Portland-Vancouver metropolitan area case, we sought to evaluate the effectiveness of urban growth boundaries among the individual counties, as well as the degree to which outcomes in Clark County, WA differed from outcomes in the three Oregon counties. We first estimated four individual county models to test the influence of urban growth boundaries on county-specific development outcomes. We then estimated a single "pooled" model to examine whether development outcomes in Clark County, WA are statistically different than those in the three Oregon counties.

For the individual county models, urban growth boundaries imply two treatments: (1) land-use observations outside urban growth boundaries, and (2) land-use observations inside urban growth boundaries. We defined a dependent variable DEVELOPED as equal to 1 if land was observed to be in a low-density residential or urban use and 0 otherwise. We specified the regression equation to be estimated for each county as:

DEVELOPED $=\alpha_{0}+\alpha_{1}$ UGB $+\alpha_{2}$ TIME $+\alpha_{3}$ TIME $*$ UGB $+\varepsilon$

for which explanatory variables are defined in Table 1 , the $\alpha_{i}$ are coefficients to be estimated, and $\varepsilon$ is random error. The model commonly is estimated using ordinary least squares regression (e.g., Wooldridge, 2006). Although, the binary dependent variable typically could lead to predicted values falling outside of the $0-1$ interval, ordinary least squares greatly simplifies estimating the
Table 1

Definitions and means of dependent and independent variables.

\begin{tabular}{|c|c|c|}
\hline Variable & Definition & Mean \\
\hline DEVELOPED & $\begin{array}{l}\text { Variable equal to } 1 \text { if observation is in } \\
\text { low-density residential or urban land use; } 0 \\
\text { otherwise }\end{array}$ & - \\
\hline UGB & $\begin{array}{l}\text { Variable equals } 1 \text { if observation is located } \\
\text { inside current in urban growth boundary (or } \\
\text { exception area in Oregon); } 0 \text { otherwise }\end{array}$ & 0.32 \\
\hline TIME & $\begin{array}{l}\text { Variable equals } 1 \text { if observation is from } 2005 \text { to } \\
\text { 2006; } 0 \text { otherwise }\end{array}$ & 0.50 \\
\hline UGB*TIME & $\begin{array}{l}\text { Variable equals } 1 \text { if observation is located } \\
\text { inside current in urban growth boundary } \\
\text { and if observation is from } 2005 \text { to } 2006 ; 0 \\
\text { otherwise }\end{array}$ & \\
\hline CLARK & $\begin{array}{l}\text { Variable equals } 1 \text { if observation is in Clark } \\
\text { County; } 0 \text { otherwise }\end{array}$ & 0.24 \\
\hline $\begin{array}{l}\text { DISTANCE TO } \\
\text { CITY }\end{array}$ & $\begin{array}{l}\text { Estimated travel time in minutes to Portland, } \\
\text { OR city center assuming } 88 \mathrm{~km} / \mathrm{h} \text { on } \\
\text { freeways, } 72 \mathrm{~km} / \mathrm{h} \text { on highways, and } 56 \mathrm{~km} / \mathrm{h} \\
\text { on all other roads. }\end{array}$ & 43.18 \\
\hline SLOPE & Percent slope & 14.81 \\
\hline ELEVATION & Elevation in 1000 s of meters & 0.24 \\
\hline
\end{tabular}

Note: $N=6808$.

treatment (or policy) effect relative to alternative estimation methods such as logit or probit which would yield estimated treatment effects that would be nonlinear functions of all of the independent variables and estimated coefficients (Dempsey \& Plantinga, 2013). Also, in our case the explanatory variables are dummy variables that describe exclusive and exhaustive categories such that predicted values all will fall between 0 and 1 (Wooldridge, 2006).

The resulting estimated coefficients identify incremental percentage point differences in the proportion of low-density residential or urban (DEVELOPED) land given the time and locations represented by the independent variables (Fig. 3). The intercept term $\alpha_{0}$ is the proportion of developed land in 1974-1976 outside of current urban growth boundaries (base case). The coefficient $\alpha_{1}$ (for UGB) is the incremental percentage point difference in the proportion of developed land in 1974-1976 inside current urban growth boundaries relative to lands outside urban growth boundaries owing to its greater proximity to the urban center. We expected this coefficient to be positive based on previous research suggesting that lands eventually designated as inside urban growth boundaries typically were more likely to develop than lands eventually designated as outside urban growth boundaries (Kline, 2005). The coefficient $\alpha_{2}$ (for TIME) is the incremental percentage point increase in the developed land proportion on all lands from 1974-1976 to 2005-2006, relative to the base case $\alpha_{0}$ owing

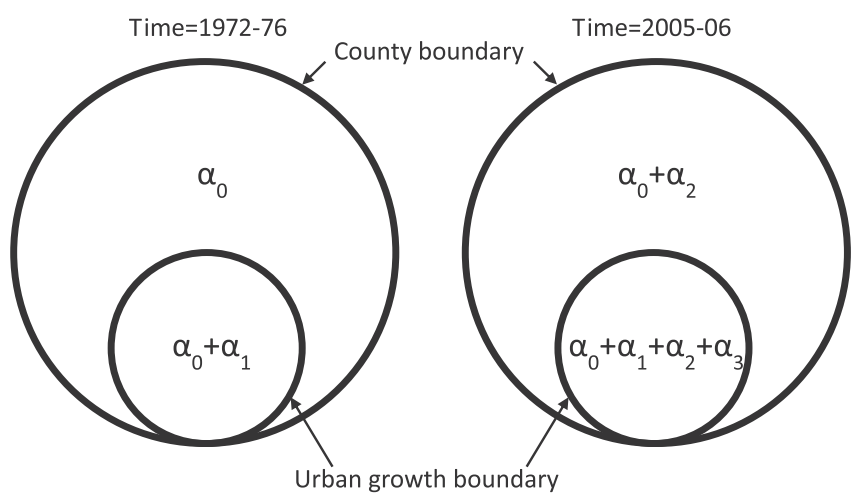

Fig. 3. Visual definition of estimated coefficients ( $\alpha_{0}$ though $\alpha_{3}$ ) reported for individual county difference-in-differences regression models (without location controls, Table 3) showing their incremental contribution to computing the proportion of low-density residential and urban land, inside and outside urban growth boundaries for 1972-1976 and 2005-2006. 
to regional population growth and other time-varying factors. The coefficient $\alpha_{3}$ (for TIME*UGB) is the incremental percentage point increase in the developed land proportion in 2005-2006 inside current urban growth boundaries. The $\alpha_{3}$ coefficient measures the degree to which each county's land-use policies, including implementation of urban growth boundaries, have concentrated development from 1974-1976 to 2005-2006 after controlling for the effects of urban center proximity and time.

The pooled four-county model implies four treatments: (1) Oregon observations (on the Portland side of the Columbia River) outside urban growth boundaries, (2) Oregon observations inside urban growth boundaries, (3) Clark County, WA observations (on the Vancouver side of the Columbia River) outside urban growth boundaries, and (4) Clark County observations inside urban growth boundaries. This four-treatment structure implies an expanded difference-in-difference-in-differences estimator and the regression equation:

$$
\begin{aligned}
\text { DEVELOPED }= & \beta_{0}+\beta_{1} \mathrm{UGB}+\beta_{2} \text { TIME }+\beta_{3} \text { TIME } * \text { UGB } \\
& +\beta_{4} \text { CLARK }+\beta_{5} \text { CLARK } * \text { UGB }+\beta_{6} \text { CLARK } * \text { TIME } \\
& +\beta_{7} \text { CLARK } * \text { TIME } * \text { UGB. }
\end{aligned}
$$

The interpretations of the estimated coefficients $\beta_{0}, \beta_{1}, \beta_{2}$, and $\beta_{3}$ are similar to those for the $\alpha$ 's estimated in the individual county models, except that they now refer to development proportions for the three Oregon counties combined (Fig. 4). The estimated coefficients $\beta_{4}-\beta_{7}$ for the variables CLARK, CLARK*UGB, CLARK*TIME, and CLARK*TIME*UGB characterize Clark County, WA development both outside and inside urban growth boundaries relative to the three Oregon counties.

Specifically, the coefficient $\beta_{4}$ (for CLARK) is the incremental percentage point difference in the proportion of developed land in Clark County in 1974-1976 outside current urban growth boundaries relative to the three Oregon counties base case $\beta_{0}$ (Fig. 4). The coefficient $\beta_{5}$ (for CLARK ${ }^{*} \mathrm{UGB}$ ) is the incremental percentage point difference in the developed land proportion in Clark County 1974-1976 inside current urban growth boundaries relative to that for the three Oregon counties. The coefficient $\beta_{6}$ (for CLARK*TIME) is the incremental percentage point difference in the percentage point change in the developed land proportion on all Clark County lands from 1974-1976 to 2005-2006, relative to the three Oregon counties-how much more or less Clark County developed compared to the three Oregon counties. The coefficient $\beta_{7}$ (for CLARK ${ }^{*}$ TIME*UGB) is the incremental percentage point difference in the developed land proportion in Clark County in 2005-2006 inside current urban growth boundaries relative to that for the three Oregon counties-how much more or less Clark County concentrated development within urban growth boundaries compared to the three Oregon counties.

We also estimated an alternative set of county-specific and pooled models that included additional explanatory variables to control for locational characteristics that commonly are found to influence development, including city proximity, slope, and elevation (e.g., Kline, Azuma, \& Moses, 2003; Kline, Moses, Azuma, \& Gray, 2009) (Table 1). The variable DISTANCE TO CITY is an estimate of the driving time in minutes to Portland city center based on the regional road network. We expected that greater proximity (shorter driving times) would correlate with higher development rates. We expected that higher values of SLOPE would be correlated with lower rates of development, given that building on steeper slopes tends to be more costly than building on level ground, and may even invoke additional land-use restrictions. We expected that higher values of ELEVATION would be correlated with higher development rates given that higher elevations more likely provide scenic views. Additionally, because higher elevations in the study region tend to have lower quality soils, we would expect such lands to be less viable for intensive farming activity and less likely to be zoned for exclusive farming, and thus more prone to development.

Because the data include two observations of each point at two occasions in time, the estimated coefficients describing the change in development over time $\left(\beta_{2}\right)$ and the influence of urban growth boundaries on development over time $\left(\beta_{3}\right)$ remain unchanged by the inclusion of the time-invariant DISTANCE TO CITY, SLOPE, and ELEVATION locational characteristics (Dempsey \& Plantinga, 2013). We did not include an additional explanatory variable representing population growth, because population growth would affect the region as a whole, with changes in any individual county influenced by land-use policies and urban growth in all other counties. Moreover, the difference-in-differences model structure means that any potential effects of time-varying factors, such as population, are entirely captured in the TIME variable.

Lastly, we compared the influence of each county's urban growth boundary at containing new development (low-density and urban combined) using a simple measure of containment suggested by Dempsey and Plantinga (2013) and computed using the model coefficients defined for the difference-in-differences models as:

Containment $=\frac{\alpha_{3}}{\alpha_{2}+\alpha_{3}}$

The numerator is the incremental increase in development owing to containment within urban growth boundaries, while the denominator is the total increase in development within urban growth boundaries owing to containment as well as time. The ratio would equal 1 if all development were successfully contained within urban growth boundaries and 0 if development within urban growth boundaries equaled development outside (Dempsey \& Plantinga, 2013). We computed a comparable containment measure for the three Oregon counties combined by replacing the $\alpha$ 's with their $\beta$ counterparts from the pooled model.

\section{Results}

\subsection{Land use and development in counties}

The proportions of nonfederal land in different uses at the start and end of 1974-1976 to 2005-2006 study period indicate that Multnomah County began with a much higher percentage of urban land (41\% urban) than other counties (Table 2). Over the 30-year span, urban land in Multnomah, Washington, and Clark counties increased equally in absolute percentage terms by $8 \%$, while Clackamas County experienced less urbanization (3\%). For low-density residential land, Clark and Clackamas counties experienced the largest absolute percentage increases, at $9 \%$ and $7 \%$; increases in Washington and Multnomah counties were substantially lower at $2 \%$ and $1 \%$. In all counties, development mostly has come at the expense of mixed forest-agriculture or intensive agriculture land, with comparably less wildland forest developed in absolute percentage terms (Table 2).

Urban development outside urban growth boundaries was minimal in the three Oregon counties, with growth inside boundaries continuing (Fig. 5). By contrast, urban development outside urban growth boundaries in Clark County was more substantial, likely reflecting their later urban growth boundary implementation and greater discretion afforded to counties under Washington's Growth Management Act. Most development outside urban growth boundaries for all four counties has been low-density residential. Low-density development outside urban growth boundaries increased more than threefold in Clark County (2.1-7.1\%), compared to a two-fold increase for the three Oregon counties combined. However, in absolute difference terms, the percentages converted to low density development in Clackamas (6\%), 


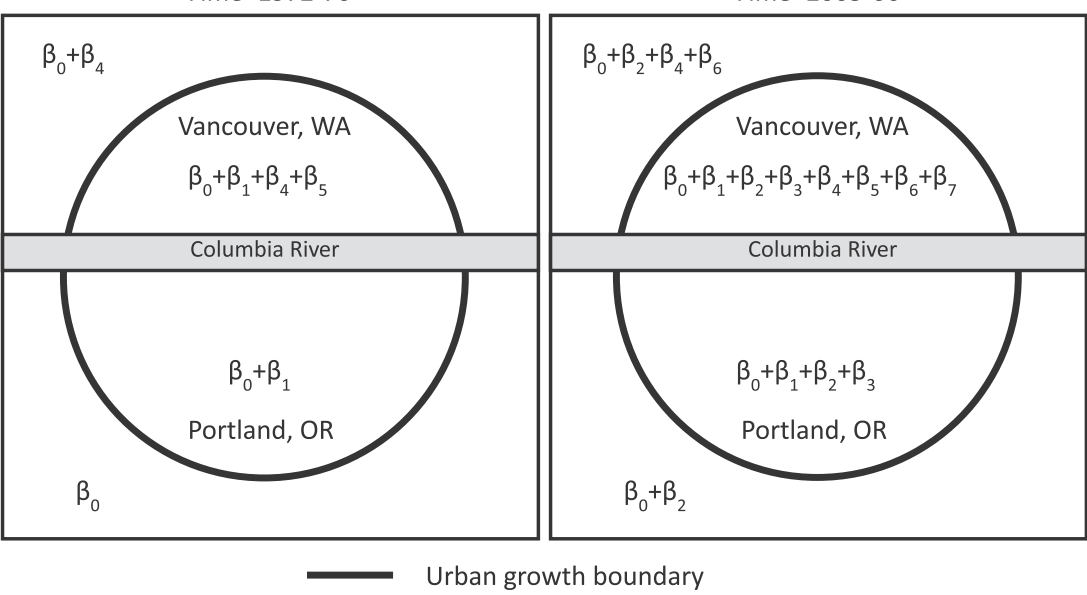

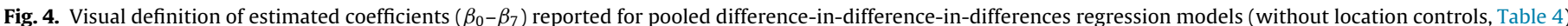

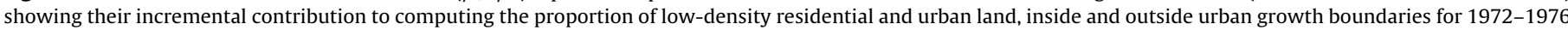
and 2005-2006, on the Portland, OR versus Vancouver, WA sides of the Columbia River.

Multnomah (6.1\%), and Clark county (5\%) counties are comparable and much higher than the amount converted in Washington County (1.7\%). These development rates translate to comparable rates of resource land conservation outside urban growth boundaries, with Washington County seemingly besting other counties (Fig. 5).

Urban development inside of urban growth boundaries increased more rapidly in Washington County in absolute percentage terms $(34.0-66.5 \%$, or $+32.5 \%)$ than in the other three counties (Clark, $+17.0 \%$; Clackamas, $+12.6 \%$ and Multnomah, $+13.4 \%$ ) (Fig. 5). Notably, Multnomah was the only county to experience a drop in low-density development inside the urban growth boundary over the study period. Clackamas and Multnomah Counties both began and ended the period with majority proportions of low-density residential and urban land combined inside urban growth boundaries, and Washington County largely had caught up to them by the study period's end. Clark County began the study period with the lowest proportion of combined development land (35.5\%) and ended with the lowest proportion (66.1\%) despite experiencing a rather significant percentage point increase (30.6\%), second only to Washington County (39.2\%). The prevalence of resource lands inside urban growth boundaries in Clark County in 2006 (33.9\%) suggests a rather significant supply of buildable land, when compared to that of the Oregon counties (Fig. 5).

\subsection{County difference-in-differences models}

The estimated county models (Table 3 ) are highly statistically significant based on $F$-tests $(P<0.0001)$, with adjusted $R^{2}$ values ranging from 0.31 for Clark County to 0.58 for Washington County. Because they describe percentage point differences associated with time and urban growth boundary effects, the estimated coefficients for the Intercept, UGB, TIME, and UGB*TIME variables can be used to re-compute the combined (low-density residential and urban) land-use proportions reported in Fig. 5 for each of the four

Table 2

Proportion (\%) of nonfederal land in different uses in study area counties.

\begin{tabular}{|c|c|c|c|c|}
\hline \multirow[t]{2}{*}{ Land use } & \multicolumn{2}{|c|}{ Clackamas County, OR } & \multicolumn{2}{|c|}{ Three Oregon counties ${ }^{\mathrm{a}}$} \\
\hline & 1974 & 2005 & 1974 & 2005 \\
\hline Urban & 5 & 8 & 12 & 17 \\
\hline Low-density residential & 14 & 21 & 9 & 13 \\
\hline Intensive agriculture & 24 & 20 & 25 & 21 \\
\hline Mixed forest-agriculture & 13 & 9 & 11 & 8 \\
\hline \multirow[t]{3}{*}{ Wildland forest } & 44 & 42 & 43 & 41 \\
\hline & \multicolumn{2}{|c|}{ Multnomah County, OR } & \multicolumn{2}{|c|}{ Clark County, WA } \\
\hline & 1974 & 2005 & 1976 & 2006 \\
\hline Urban & 41 & 49 & 7 & 15 \\
\hline Low-density residential & 9 & 10 & 12 & 21 \\
\hline Intensive agriculture & 15 & 9 & 20 & 13 \\
\hline Mixed forest-agriculture & 7 & 6 & 17 & 12 \\
\hline \multirow[t]{3}{*}{ Wildland forest } & 28 & 26 & 44 & 39 \\
\hline & \multicolumn{2}{|c|}{ Washington County, OR } & \multicolumn{2}{|c|}{ All four counties } \\
\hline & 1974 & 2005 & 1974-1976 & 2005-2006 \\
\hline Urban & 7 & 15 & 10 & 16 \\
\hline Low-density residential & 3 & 5 & 10 & 15 \\
\hline Intensive agriculture & 32 & 26 & 24 & 19 \\
\hline Mixed forest-agriculture & 10 & 8 & 13 & 9 \\
\hline Wildland forest & 48 & 46 & 43 & 41 \\
\hline
\end{tabular}

Note: Based on data reported in Lettman (2011) for Oregon counties and Gray et al. (2013) for Clark County.

a Clackamas, Multnomah, and Washington counties. 
Clackamas County, OR

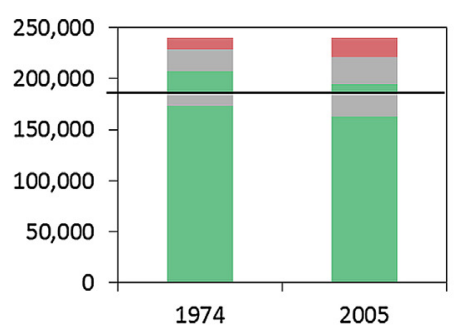

Multnomah, OR

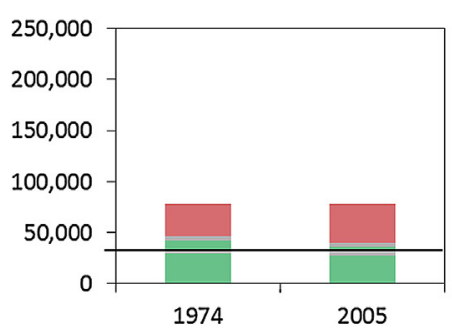

Washington County, OR

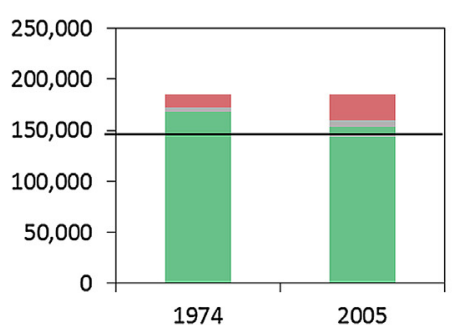

\begin{tabular}{llc}
\hline Land use & 1974 & 2005 \\
\hline \multicolumn{3}{l}{ Inside urban } \\
Urbawth boundary & $23.0 \%$ & $35.6 \%$ \\
Low-density & 38.9 & 48.2 \\
Resource & 38.1 & 16.2 \\
\hline Outside urban growth boundary \\
Urban & $0.1 \%$ & $0.1 \%$ \\
Low density & 6.5 & 12.5 \\
Resource & 93.4 & 87.4 \\
\hline
\end{tabular}

\begin{tabular}{lll}
\hline Land use & 1974 & 2005 \\
\hline Inside urban & growth boundary \\
Urban & $69.1 \%$ & $82.5 \%$ \\
Low-density & 9.4 & 7.3 \\
Resource & 21.5 & 10.2 \\
\hline Outside urban & growth boundary \\
Urban & $0.0 \%$ & $0.6 \%$ \\
Low density & 7.8 & 13.9 \\
Resource & 92.2 & 85.5 \\
\hline
\end{tabular}

\begin{tabular}{lll}
\hline Land use & 1974 & 2005 \\
\hline Inside urban & growth boundary \\
Urban & $34.0 \%$ & $66.5 \%$ \\
Low-density & 10.3 & 17.0 \\
Resource & 55.7 & 16.5 \\
\hline Outside urban & growth boundary \\
Urban & $0.3 \%$ & $0.3 \%$ \\
Low density & 0.5 & 2.2 \\
Resource & 99.2 & 97.5 \\
\hline
\end{tabular}

Three Oregon Counties

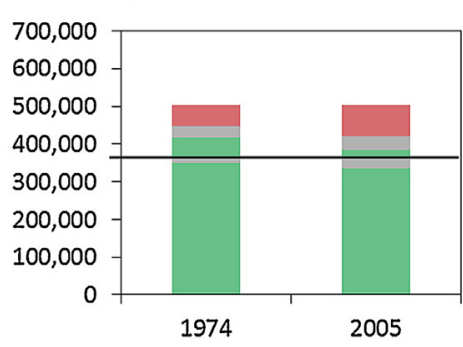

Clark County, WA

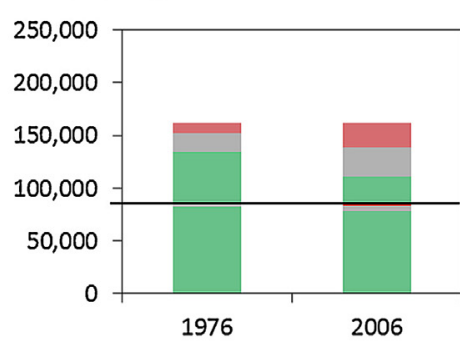

\begin{tabular}{|c|c|c|}
\hline Land use & 1976 & 2006 \\
\hline \multicolumn{3}{|c|}{ Inside urban growth boundary } \\
\hline Urban & $12.9 \%$ & $29.9 \%$ \\
\hline Low-density & 22.6 & 36.2 \\
\hline Resource & 64.6 & 33.9 \\
\hline \multicolumn{3}{|c|}{ Outside urban growth boundary } \\
\hline Urban & $1.0 \%$ & $1.4 \%$ \\
\hline Low density & 2.1 & 7.1 \\
\hline Resource & 96.9 & 91.5 \\
\hline
\end{tabular}

All four counties

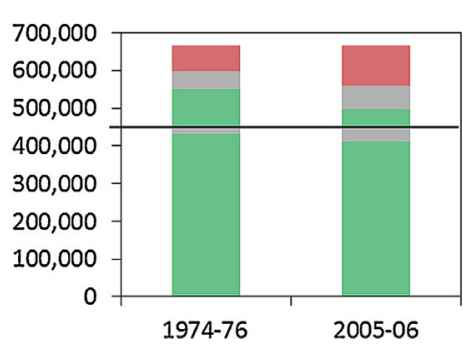

\begin{tabular}{lll}
\hline Land use & 1974 & 2005 \\
\hline Inside urban & growth boundary \\
Urban & $41.8 \%$ & $60.0 \%$ \\
Low-density & 21.0 & 25.8 \\
Resource & 37.2 & 14.2 \\
\hline Outside urban & growth boundary \\
Urban & $0.2 \%$ & $0.2 \%$ \\
Low density & 4.2 & 8.4 \\
Resource & 95.6 & 91.4 \\
\hline
\end{tabular}

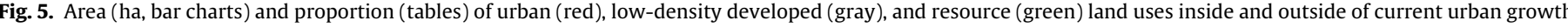

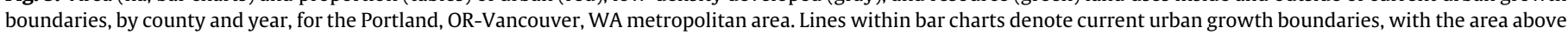
the bar indicating nonfederal land inside the urban growth boundary, and the area below the bar indicating nonfederal land outside the urban growth boundary.

counties. Slight differences do occur due to rounding. The estimated coefficients also enable testing for the statistical significance of differences in developed land proportions.

In the Clackamas County model without location controls, the estimated coefficient $\alpha_{0}=0.066$ indicates that $6.6 \%$ of land outside of current urban growth boundaries was developed in 1974-1976 (Table 3), consistent with the percentage reported in Fig. 5. The estimated coefficient for UGB $\left(\alpha_{1}=0.552\right)$ indicates that in 1974-1976 the developed land proportion was 55.2 percentage points higher inside urban growth boundaries, or $61.8 \%$ (i.e., $\alpha_{0}+\alpha_{1}=0.066+0.552=0.618$ ), again consistent with Fig. 5 . The estimated coefficient for TIME $\left(\alpha_{2}=0.060\right)$ indicates that by 2005-2006, the proportion of developed land-both outside and inside urban growth boundaries-increased by an average 6 percentage points. The estimated coefficient for UGB*TIME $\left(\alpha_{3}=0.159\right)$ indicates that by 2005-2006, the developed land proportion inside urban growth boundaries had increased an additional 15.9 percentage points relative to lands located outside urban growth boundaries. The statistical significance of $\alpha_{3}$ suggests that land-use planning helped to concentrate development inside urban growth boundaries in Clackamas County over the 30 -year period.

Similar interpretations of the estimated coefficients can be made for the other county models. In Multnomah County, developed land accounted for $7.8 \%$ of land outside urban growth boundaries in 1974-1976 $\left(\alpha_{0}=0.078\right)$ and was 70.6 percentage points higher $\left(\alpha_{1}=0.706\right.$ ) inside urban growth boundaries (Table 3 ). Over time, the proportion of developed lands-both outside and inside urban growth boundaries-increased by 6.6 percentage points $\left(\alpha_{2}=0.066\right)$. The estimated coefficient for UGB*TIME would indicate that by 2005-2006, the developed land proportion inside urban growth boundaries had increased an additional 4.8 percentage points $\left(\alpha_{3}=0.048\right)$ above that outside urban growth boundaries. However, the estimated coefficient $\alpha_{3}$ is not statistically significant $(P=0.3295)$. This suggests that urban growth boundaries have not had much influence on where development occurs in Multnomah County when development includes lowdensity and urban uses combined. We note, however, that based on Fig. 5 most Multnomah County development outside urban growth boundaries was low-density.

Results for Washington County indicate that in 1974-1976, only a small proportion of land outside urban growth boundaries was developed $\left(\alpha_{0}=0.008, P=0.3406\right)$, but that proportion was 43.5 percentage points higher $\left(\alpha_{1}=0.435\right)$ inside urban growth boundaries (Table 3 ). The developed land proportion increased only slightly for all lands from 1974-2005 to 2005-2006 $\left(\alpha_{2}=0.017, P=0.1444\right)$, but the increase was 37.5 percentage points higher on lands inside urban growth boundaries $\left(\alpha_{3}=0.375\right)$, suggesting significant containment of development within urban growth boundaries in Washington County. In Clark County, 3.1\% of land now located outside urban growth boundaries was developed in 1974-1976 $\left(\alpha_{0}=0.031\right)$, and this proportion was 32.3 percentage points higher $\left(\alpha_{1}=0.323\right)$ inside urban growth boundaries (Table 3 ). The proportion of development increased on all lands by 5.5 percentage points 
Table 3

Estimated coefficients of difference-in-differences regression models describing “developed" land uses in 1974-1976 and 2005-2006, individual counties.

\begin{tabular}{|c|c|c|c|c|c|}
\hline \multirow[t]{2}{*}{ County/variable } & \multirow[t]{2}{*}{ Model parameter } & \multicolumn{2}{|c|}{ Without location controls } & \multicolumn{2}{|l|}{ With location controls } \\
\hline & & Estimated coefficient & $t$-Statistic & Estimated coefficient & $t$-Statistic \\
\hline \multicolumn{6}{|l|}{ Clackamas, OR $(N=2458)$} \\
\hline Intercept & $\alpha_{0}$ & $0.066^{* * *}$ & 6.19 & $0.233^{* * *}$ & 11.87 \\
\hline UGB & $\alpha_{1}$ & $0.552^{* * *}$ & 24.57 & $0.467^{* * *}$ & 19.77 \\
\hline TIME & $\alpha_{2}$ & $0.060^{* * *}$ & 3.96 & $0.060^{* * *}$ & 4.04 \\
\hline UGB*TIME & $\alpha_{3}$ & $0.159^{* * *}$ & 5.01 & $0.159^{* * *}$ & 5.12 \\
\hline DISTANCE TO CITY & $\alpha_{4}$ & - & - & $-0.004^{* * *}$ & -7.51 \\
\hline SLOPE & $\alpha_{5}$ & - & - & -0.000 & -0.58 \\
\hline ELEVATION & $\alpha_{6}$ & - & - & $0.157^{* * *}$ & 3.22 \\
\hline Summary statistics: & & Adj. $R^{2}=0.40, F=552.5$ & & Adj. $R^{2}=0.43, F=304.8$ & \\
\hline \multicolumn{6}{|l|}{ Multnomah, $O R(N=824)$} \\
\hline Intercept & $\alpha_{0}$ & $0.078^{* * *}$ & 2.94 & $0.522^{* * *}$ & 9.88 \\
\hline UGB & $\alpha_{1}$ & $0.706^{* * *}$ & 20.49 & $0.453^{* * *}$ & 10.60 \\
\hline TIME & $\alpha_{2}$ & $0.066^{*}$ & 1.76 & $0.066^{*}$ & 1.88 \\
\hline UGB*TIME & $\alpha_{3}$ & 0.048 & 0.98 & 0.048 & 1.04 \\
\hline DISTANCE TO CITY & $\alpha_{4}$ & - & - & $-0.012^{* * *}$ & -7.21 \\
\hline SLOPE & $\alpha_{5}$ & - & - & $-0.005^{* * *}$ & -6.54 \\
\hline ELEVATION & $\alpha_{6}$ & - & - & 0.075 & 0.67 \\
\hline Summary statistics: & & Adj. $R^{2}=0.53, F=304.6$ & & Adj. $R^{2}=0.58, F=192.3$ & \\
\hline \multicolumn{6}{|c|}{ Washington, $O R(N=1922)$} \\
\hline Intercept & $\alpha_{0}$ & 0.008 & 0.95 & $0.112^{* * *}$ & 6.54 \\
\hline UGB & $\alpha_{1}$ & $0.435^{* * *}$ & 23.84 & $0.383^{* * *}$ & 19.49 \\
\hline TIME & $\alpha_{2}$ & 0.017 & 1.46 & 0.017 & 1.48 \\
\hline UGB*TIME & $\alpha_{3}$ & $0.375^{* * *}$ & 14.51 & $0.375^{* * *}$ & 14.68 \\
\hline DISTANCE TO CITY & $\alpha_{4}$ & - & - & $-0.003^{* * *}$ & -6.22 \\
\hline SLOPE & $\alpha_{5}$ & - & - & 0.000 & 0.08 \\
\hline ELEVATION & $\alpha_{6}$ & - & - & $0.155^{* * *}$ & 3.21 \\
\hline Summary statistics: & & Adj. $R^{2}=0.58, F=872.0$ & & Adj. $R^{2}=0.59, F=454.3$ & \\
\hline \multicolumn{6}{|l|}{ Clark, WA $(N=1604)$} \\
\hline Intercept & $\alpha_{0}$ & $0.031^{*}$ & 1.72 & $0.264^{* * *}$ & 7.64 \\
\hline UGB & $\alpha_{1}$ & $0.323^{* * *}$ & 12.39 & $0.246^{* * *}$ & 8.58 \\
\hline TIME & $\alpha_{2}$ & $0.055^{* *}$ & 2.15 & $0.055^{* *}$ & 2.19 \\
\hline UGB*TIME & $\alpha_{3}$ & $0.252^{* * *}$ & 6.84 & $0.252^{* * *}$ & 6.98 \\
\hline DISTANCE TO CITY & $\alpha_{4}$ & - & - & $-0.007^{* * *}$ & -7.83 \\
\hline SLOPE & $\alpha_{5}$ & - & - & 0.001 & 1.39 \\
\hline ELEVATION & $\alpha_{6}$ & - & - & $0.368^{* * *}$ & 4.28 \\
\hline Summary statistics: & & Adj. $R^{2}=0.31, F=243.3$ & & Adj. $R^{2}=0.34, F=138.1$ & \\
\hline
\end{tabular}

Note:

* Indicates that the probability of the $t$-statistic for each coefficient exceeding the critical $t$-value is greater than $90 \%$. Variables are defined in Table 1.

** Indicates that the probability of the $t$-statistic for each coefficient exceeding the critical $t$-value is greater than $95 \%$. Variables are defined in Table 1.

${ }^{* * *}$ Indicates that the probability of the $t$-statistic for each coefficient exceeding the critical $t$-value is greater than $99 \%$. Variables are defined in Table 1.

$\left(\alpha_{2}=0.055\right)$ from 1974-1976 to 2005-2006, and increased an additional 25.2 percentage points $\left(\alpha_{3}=0.252\right)$ inside urban growth boundaries, suggesting statistically significant containment of development inside urban growth boundaries for Clark County.

Individual county models estimated with location control variables indicate that the proportion of developed land is highly correlated with the driving time to the Portland, OR city center as evidenced by the negative and statistically significant $(P<0.01)$ estimated coefficients for DISTANCE TO CITY. Specifically, greater proximity to the Portland, OR city center (smaller values for DISTANCE TO CITY) is correlated with higher proportions of developed land. Topographical characteristics also are shown to be correlated with the proportion of developed land, depending on county. SLOPE is negatively correlated with the proportion of developed land in Multnomah County. ELEVATION is positively correlated with the proportion of developed land in Clackamas, Washington, and Clark Counties. Although the location control variables alter the estimated values for the $\alpha_{0}$ and $\alpha_{1}$ coefficients (for the intercept and UGB terms) by controlling for the effects of city proximity, slope, and elevation on development observed at the initial observation period, they do not change our fundamental results regarding the incremental impact of land-use planning and urban growth boundaries on development-specifically the estimated coefficients $\alpha_{2}$ and $\alpha_{3}$ for TIME and UGB*TIME.

\subsection{Pooled difference-in-difference-in-differences model}

The estimated coefficients for the pooled model (Table 4) describe the degree to which differences in the proportions of developed land reported for the three Oregon counties are statistically different from those for Clark County, WA. The model is highly statistically significant based on $F$-tests $(F=830, \mathrm{df}=7, P<0.0001)$, with an adjusted $R^{2}$ of 0.46 . Similar to the individual county models, because the estimated coefficients are incremental percentage point differences owing to the time and urban growth boundary effects, they can be used to re-compute the proportions of developed land with respect to urban growth boundary location (outside versus inside) and time period (1974-1976 versus 2005-2006) reported in Fig. 5 for the three Oregon counties combined and Clark County.

The estimated coefficient $\beta_{0}=0.044$ indicates that $4.4 \%$ of the land in Oregon counties and located outside of current urban growth boundaries was developed in 1974-1976 (Table 4). The estimated coefficient for UGB $\left(\beta_{1}=0.585\right)$ indicates that the proportion of developed land inside urban growth boundaries in the three Oregon counties in 1974-1976 was 58.5 percentage points higher, or $62.9 \%$ (i.e., $\beta_{0}+\beta_{1}=0.044+0.585=0.629$ ). The estimated coefficient for TIME ( $\beta_{2}=0.043$ ) indicates that by $2005-2006$, the developed land proportion in the three Oregon counties-both outside and inside urban growth boundaries-increased by an average 
Table 4

Estimated coefficients of the pooled difference-in-difference-in-differences regression model describing developed land uses in 1974-1976 and 2005-2006, all counties.

\begin{tabular}{|c|c|c|c|c|c|}
\hline \multirow[t]{2}{*}{ Variable } & \multirow[t]{2}{*}{ Model parameter ${ }^{\mathrm{a}}$} & \multicolumn{2}{|c|}{ Without location controls } & \multicolumn{2}{|l|}{ With location controls } \\
\hline & & Estimated coefficient & t-Statistic & Estimated coefficient & $t$-Statistic \\
\hline Intercept & $\beta_{0}$ & $0.044^{* * *}$ & 5.89 & $0.200^{* * *}$ & 16.02 \\
\hline UGB & $\beta_{1}$ & $0.585^{* * *}$ & 41.53 & $0.495^{* * *}$ & 32.81 \\
\hline TIME & $\beta_{2}$ & $0.043^{* * *}$ & 4.11 & $0.043^{* * *}$ & 4.18 \\
\hline TIME*UGB & $\beta_{3}$ & $0.187^{* * *}$ & 9.38 & $0.187^{* * *}$ & 9.55 \\
\hline CLARK & $\beta_{4}$ & -0.013 & -0.73 & -0.009 & -0.51 \\
\hline CLARK*UGB & $\beta_{5}$ & $-0.261^{* * *}$ & -9.78 & $-0.231^{* * *}$ & -8.76 \\
\hline CLARK*TIME & $\beta_{6}$ & 0.012 & 0.48 & 0.012 & 0.48 \\
\hline CLARK*TIME*UGB & $\beta_{7}$ & $0.066^{*}$ & 1.74 & $0.066^{*}$ & 1.77 \\
\hline DISTANCE TO CITY & - & - & - & $-0.004^{* * *}$ & -12.63 \\
\hline SLOPE & - & - & - & $-0.001^{* * *}$ & -3.43 \\
\hline ELEVATION & - & - & - & $0.223^{* * *}$ & 6.90 \\
\hline Summary statistics: & & \multicolumn{2}{|c|}{$\begin{array}{l}N=6808, \text { Adj. } R^{2}=0.46, F=830, \mathrm{dF}=7, \\
\operatorname{Pr}>F=0.0001\end{array}$} & \multicolumn{2}{|c|}{$\begin{array}{l}N=6808, \text { Adj. } R^{2}=0.48, F=625, \mathrm{dF}=10 \\
\operatorname{Pr}>F=0.0001\end{array}$} \\
\hline
\end{tabular}

Note:

* Indicates that the probability of the $t$-statistic for each coefficient exceeding the critical $t$-value is greater than $90 \%$. Variables are defined in Table 1 .

${ }^{* * *}$ Indicates that the probability of the $t$-statistic for each coefficient exceeding the critical $t$-value is greater than $99 \%$. Variables are defined in Table 1 .

4.3 percentage points. The estimated coefficient for TIME*UGB $\left(\beta_{3}=0.187\right)$ indicates that by $2005-2006$, the developed land proportion inside urban growth boundaries in the three Oregon counties was 18.7 percentage points higher relative to outside urban growth boundaries, suggesting that on average land-use planning had the intended effect of concentrating development within urban growth boundaries in Oregon counties during the 30-year period.

The estimated coefficient for CLARK $\left(\beta_{4}=-0.013\right)$ would indicate that in 1974-1976, the proportion of developed land outside urban growth boundaries in Clark County was 1.3 percentage points less than that for the Oregon counties, or $3.1 \%$ (i.e., $\beta_{0}+\beta_{1}=0.031$ ) (Table 4). However, the t-statistic for $\beta_{4}$ suggests that this difference is not statistically significant $(P=0.4649)$, suggesting that in 1974-1976 Clark County development outside urban growth boundaries could not be distinguished from that for the three Oregon counties. The estimated coefficient for CLARK*UGB $\left(\beta_{5}=-0.261\right)$ indicates that the developed land proportion for Clark County in 1974-1976 now located inside urban growth boundaries was 26.1 percentage points less than that proportion for the three Oregon counties, or $35.5 \%$ (i.e., $\beta_{0}+\beta_{1}+\beta_{4}+\beta_{5}=0.355$ ). This confirms that in 1974-1976, Clark County land now located within urban growth boundaries was significantly less developed relative to the average for land located inside urban growth boundaries in the three Oregon counties.

The estimated coefficient for CLARK*TIME $\left(\beta_{6}=0.012\right)$ would indicate that by 2005-2006, development on all lands in Clark County had increased by an average 1.2 percentage points more than the comparable increase for the three Oregon counties. However, the estimated coefficient is not statistically significant $(P=0.6344)$, suggesting that on average, the increase in development on all lands in Clark County could not be distinguished from that experienced in the Oregon counties. The estimated coefficient for CLARK*TIME*UGB $\left(\beta_{7}=0.066\right)$ indicates that the proportion of developed land in Clark County inside urban growth boundaries was 6.6 percentage points higher than the comparable increase for the three Oregon counties. This result suggests that Clark County experienced greater development on its lands inside urban growth boundaries, than did the three Oregon counties from 1974-1976 to 2005-2006.

For the pooled model estimated with location control variables, all location control estimated coefficients are highly statistically significant $(P<0.01)$. As with the individual county models, the proportion of developed land is highly correlated with the proximity to the Portland, OR city center. The proportion of development land also is negatively correlated with SLOPE and positively correlated with ELEVATION. As with the individual county models, although the location control variables control for the effects of city proximity, slope, and elevation, they do not change our fundamental results regarding the incremental impact of land-use planning and urban growth boundaries on the proportion of developed land.

\subsection{Development containment measures}

Development containment measures computed using estimated coefficients (Tables 3 and 4) for low-density and urban development models without location controls show differences among counties (Table 5). Washington County (0.957) appears most successful at containing low-density and urban development combined within its urban growth boundaries, followed by Clark County (0.821), Clackamas County (0.726), and Multnomah County (0.421). A low-density and urban development containment measure computed for the three Oregon counties combined (0.813) compared to the same measure computed for Clark County, WA (0.821), would seem to suggest that on average the Oregon and Washington portions of the Portland-Vancouver metropolitan area have been fairly similar in their success at containing low-density and urban development.

Because the estimated coefficients of the difference-indifferences regression models coincide with the development data presented in Fig. 5, it is possible to compute a set of containment

Table 5

Measures of development containment within current urban growth boundaries 1974-1976 to 2005-2006. ${ }^{\text {a }}$

\begin{tabular}{lll}
\hline County & Urban & Low-density and urban combined \\
\hline Clackamas, OR & $1.000^{\mathrm{b}}$ & $0.726^{\mathrm{c}}$ \\
Multnomah, OR & $0.955^{\mathrm{b}}$ & $0.421^{\mathrm{c}}$ \\
Washington, OR & $1.000^{\mathrm{b}}$ & $0.957^{\mathrm{c}}$ \\
Clark, WA & $0.972^{\mathrm{b}}$ & $0.821^{\mathrm{c}}$ \\
Three Oregon counties & $0.997^{\mathrm{b}}$ & $0.813^{\mathrm{d}}$ \\
\hline
\end{tabular}

a The measure is the ratio of the incremental increase in development (urban, or low-density and urban combined) owing to containment within urban growth boundaries (and exception areas in Oregon), to the total increase in development within urban growth boundaries owing to containment as well as time. The ratio equals 1 if all development was successfully contained within urban growth boundaries and 0 if development within urban growth boundaries equaled development outside urban growth boundaries (Dempsey \& Plantinga, 2013).

b Based on data describing urban development from Fig. 5.

c Based on estimated coefficients from Table 3.

d Based on estimated coefficients from Table 4. 
measures for urban development alone based on Fig. 5 values. Computation of a similar containment measure for low-density development is not possible, because a portion of low-density development is lost over time owing to its conversion to urban development. Containment measures computed for specifically urban development in the four study area counties indicate that both Clackamas (1.000) and Washington (1.000) counties, OR were fully successful at containing strictly urban development within their urban growth boundaries (Table 5). Both Multnomah County (0.955) and Clark County (0.972) also were comparatively successful. Taken along with the containment measures computed for low-density and urban development combined, it would seem that the greatest differences among counties involve the containment of specifically low-density development.

\section{Discussions}

Our results suggest that land-use planning has had a measurable though varied effect among counties in containing low-density and urban development within current urban growth boundaries in the Portland-Vancouver metropolitan area. In all but Multnomah County, we found these effects to be statistically significant. The lack of a statistically significant effect in Multnomah County may derive from Multnomah County's already highly developed condition in 1974-1976, which might have made it difficult to contain additional development within urban growth boundaries and exception areas without going above existing densities. Multnomah County may have offered less undeveloped land designated as developable during the period examined, compared to other counties, causing some development to spillover outside urban growth boundaries and exception areas.

Despite land-use controls, development occurred both inside and outside of current urban growth boundaries in all study area counties, but counties differ in the types of development that have taken place. The four counties are similar in their containment of urban development, but differ in their containment of lowdensity and urban development combined. Thus, differences owe to how well individual counties contained low-density development. Washington County did much better at containing low-density development within urban growth boundaries compared to the other counties.

Many land-use planning officials likely would agree that containing low-density development is necessary for conserving forest and agricultural land. However, if urban growth boundaries are to provide sufficient land to accommodate future population growth, one might question whether low-density development is desirable at all. We stress, however, that the low-density development category examined here arguably defines a fairly rural or dispersed form of development ( 9 or more structures per $2.59 \mathrm{~km}^{2}$ ). Had the data defined low-density development using a higher structure density threshold, we undoubtedly would have found less low-density development outside urban growth boundaries. We were reliant on the data at hand and the land-use categories as defined. Planners and policymakers interested in gathering data for evaluating landuse planning effects should carefully consider the criteria used to define land uses to ensure that they are appropriate for evaluating policy effects of interest.

Notably, our results suggest that Clark County, WA has been somewhat successful at containing development despite having experienced what some observers consider to be a less restrictive land-use planning history compared to Oregon counties. Although implemented much later than Oregon's land-use planning program, the Washington State Growth Management Act appears to be influencing Clark County development, just as the Oregon's better known Land Use Act has influenced development in Oregon.
However, our results also suggest that Clark County has taken a different approach to containing development by including a comparatively greater supply of undeveloped land within its current urban growth boundary than any of the three Oregon counties examined. This difference can be seen in the greater percentage of resource land and low-density development found inside the Clark County urban growth boundary compared to the average for the three Oregon counties.

The comparatively greater supply of developable land found within Clark County's current urban growth boundary compared to the average for the Oregon counties could owe to Clark County's urban growth boundary being drawn more expansively to accommodate expectations for significant future urban growth. This contrast with the Oregon counties is consistent with the more active involvement of the State of Oregon-via the Department of Land Conservation and Development-in county planning in Oregon relative to the greater discretion afforded to counties in the State of Washington. Concurrent research also suggests that Clark County's seemingly more expansive urban growth boundary may owe to a greater degree of political fragmentation in local politics and to the lack of an authoritative regional institution in southwest Washington comparable to Metro in the three Oregon counties (Thiers, Stephan, \& Walker, 2011). The relative absence in Clark County, WA of involvement by multiple agencies, such as Metro and the Department of Land Conservation and Development in Oregon, in the development of rules and regulations also may be a factor. In Clark County, Washington State involvement is mostly limited to a complaint-based appeals process. Regardless of the reasons, although Clark County may have avoided some political conflict by implementing a more expansive urban growth boundary, it may have set the stage for eventual loss of forest and agricultural land and greater associated ecological costs compared to the three Oregon counties.

The three Oregon counties also exhibit differences among themselves in their development patterns. With just 44.3 percent of land within its current urban growth boundary developed in 1974, Washington County's experience has been more comparable to Clark County, WA than to, say, Multnomah County, where 78.5\% of land within its urban growth boundary was already developed in 1974. In 2005-2006, 33.9\% of Clark County land within urban growth boundaries remained in forest and agricultural uses, followed in Oregon by Washington (16.5\%), Clackamas (16.2\%), and Multnomah Counties (10.2\%). Whether these differences owe in any way to the degree to which individual counties have been willing to commit undeveloped forest and agricultural lands to future development is debatable. Although we treated individual counties as distinct geographic units in our analysis, land-use planning decisions affecting the three Oregon counties are considered for the region as a whole by Metro and not by the three counties independently. As part of one system of land-use planning, county performance must be considered in the context of geography and the history of broader policy decisions particularly just prior to passage of the Oregon Land Use Act and the establishment of Metro, which were beyond the scope of our study.

Still, there are plausible explanations for differences among counties in urban growth boundary effectiveness. Some observers have suggested a willful lack of adequate enforcement in some counties, resulting in improper development mostly in exclusive agricultural use zones (1000 Friends of Oregon, 1985). Differences also could arise from: unrestricted development permitting in the years just prior to urban growth boundary enforcement; differences in soil quality and the fewer restrictions allowed on lands of low soil quality; and differences in the criteria individual counties use to determine allowable development outside urban growth boundaries. Also, following the U.S. Supreme Court decision in Lucas versus South Carolina Coastal Council (1992), which defined 
criteria for evaluating regulatory takings, Oregon allowed that any parcel deemed either too small or of insufficient soil quality to be viable for agriculture or forestry would be eligible for development. Together, these factors meant that many parcels of smaller size or poorer soil quality might eventually have qualified for development.

Multnomah County, for example, was fairly generous in granting rural subdivision and building permits just prior to urban growth boundary enforcement. This combined with a general scarcity of high-quality agricultural soils meant that significant development outside urban growth boundaries continued after enforcement. Clackamas County also granted several subdivision and building permits prior to urban growth boundary enforcement, effectively "grandfathering in" much development that occurred later outside urban growth boundaries and exception areas. Also, its generally poor agricultural soils have led Clackamas County to establish relatively small minimum parcel sizes for building in exclusive agricultural use and rural residential zones. In contrast, Washington County, with its higher quality agricultural soils, tended to enforce stronger agricultural protection policies and granted fewer subdivision and building permits prior to urban growth boundary enforcement, resulting in fewer small parcels and less development outside urban growth boundaries.

Clark County, WA also was fairly restrained in approving subdivisions and building permits just prior to urban growth boundary enforcement, largely because demand for permits was limited as few landowners or county officials expected Washington's Growth Management Act to pass. By 1994, as it became clear that efforts to delay the Act's implementation were failing, some developers rushed projects into development, causing smart growth advocates on the County Board of Commissioners to counter with a 90 day moratorium on new development (Callahan, 1994a, 1994b). This combined with overall lower demand for residential building sites owing to more limited commuting opportunities to Portland, OR meant that less development was grandfathered in.

\section{Conclusions}

We sought to determine whether urban growth boundaries are effective at containing low-density and urban development, and conserving forest and agricultural land in the Portland, ORVancouver, WA metropolitan area. We also sought to determine the degree to which these effects have varied between Oregon and Washington. Our results suggest that urban growth boundaries now mandated in both Oregon and Washington have had a measurable and statistically significant effect in containing development and conserving forest and agricultural lands. Our results also suggest that these effects have varied across individual counties, likely owing, in part, to differences in counties' initial levels of development, distinctly different land-use planning histories, and how restrictively their urban growth boundaries were drawn. These factors would seem to have contributed to the apparent level of success within counties in containing low-density and urban development and conserving resource land. Most notably, less restrictively drawn urban growth boundaries yield the appearance of successful development containment more than do more restrictive urban growth boundaries, largely because they offer up a greater supply of forest and agricultural land for future development. More fully developed counties that drew their urban growth boundaries more restrictively, may face greater limitations to containing additional low-density and urban development simply because of a shortage of undeveloped land on which to build.

There likely are a variety of paths that cities and counties can take to contain urban growth and conserve resource land, with success not solely dependent on the timing and restrictiveness of any one growth control measure adopted. Some land-use planning likely is better than no planning, and urban growth boundaries are more effective than no urban growth boundaries. But, the specific characteristics of planning and urban growth boundary design matter for land-use outcomes over the long term. Although we focused our efforts on examining differences in land use planning effectiveness between the Oregon and Washington sides of the Portland-Vancouver metropolitan area, the difference-indifferences approach could also be used to examine effectiveness among individual counties. Such an analysis would need to consider differences in light of the variety of factors that potentially can influence development outcomes and effectiveness, potentially by examining counties on a case by case basis.

Further research in the Portland-Vancouver metropolitan area also could further refine understanding of urban growth boundary effectiveness by identifying and examining factors that influence differences in effectiveness. Another approach would be to focus on periodic boundary expansions over the 30-year span examined to observe how low-density and urban development has been influenced by specific urban growth boundary expansions across the region. Another approach would be to examine the long-term history of specific land parcels to see if, when, and how they were brought into the urban growth boundary, and if, when, and how they were developed. A similar approach would be to examine the spatial location and timing of construction permitting both inside and outside urban growth boundaries, and before and after they were implemented. Such case study approaches would enable examining how resilient socioeconomic and ecological systems-upstream riparian zones, specific habitat-types, or highquality agricultural land, for example-are to change brought about by urban growth. Lastly, additional research could examine lowdensity development using varying structure density thresholds, as well as examine the specific types of residential development that occur.

The ULTRA-Ex context, with its focus on multidisciplinary research would seem to be a good approach for addressing future research questions regarding the effectiveness of land-use planning. Future ULTRA-Ex research also could compare urban growth policies from the Portland-Vancouver region with other regions in the USA, or even internationally, to illuminate the relative success of this region at containing urban growth (Rosan, 2007). Sustainable management of urbanizing landscapes will depend on evaluating and addressing both the socioeconomic and ecological impacts of land-use change and development, and the degree to which particular system elements may require protection or enhancement. For example, other Portland-Vancouver ULTRA-Ex research examines the role of cities in this region in maintaining environmental quality of urban ecosystems as these cities become more densely populated (e.g., Chang et al., 2014; Ozawa \& Yeakley, 2007; Thiers et al., 2011; Yeakley et al., 2012). The Portland-Vancouver ULTRA-Ex collaboration creates linkages between land-use policy evaluations such as ours with biophysical and social analyses to determine what actual consequences differences in land-use policy have for urban socio-ecological systems.

\section{Acknowledgments}

Partial funding for this study was provided by the National Science Foundation to the Portland-Vancouver ULTRA-Ex project, with grant numbers 0948983, 0948826, and 0949042. We thank four anonymous reviewers for many helpful comments.

\section{References}

1000 Friends of Oregon. (1985). Counties are creating thousands of martini farms. 1000 Friends of Oregon Newsletter, 10(1), 1-2. 
Abbott, C., Howe, D., \& Adler, S. (1994). Introduction. In C. Abbott, D. D. Howe, \& S. Adler (Eds.), Planning the Oregon way (pp. ix-xxiv). Corvallis, OR: Oregon State University Press.

Bengston, D. N., Fletcher, J. O., \& Nelson, K. C. (2004). Public policies for managing urban growth and protecting open space: Policy instruments and lessons learned in the United States. Landscape and Urban Planning, 69(2-3), 271-286.

Callahan, L. (1994a). Group seeks growth moratorium. The Columbian, September, A2.

Callahan, L. (1994b). Rural development halted. The Columbian, November, A1.

Chang, H., Thiers, P., Netusil, N. R., Yeakley, J. A., Rollwagen-Bollens, G., Bollens, S. M. et al. (2014). Relationships between environmental governance and water quality in growing metropolitan areas: A synthetic view through the coupled natural and human system lens. Hydrology and Earth System Science, 18, 1383-1395.

Clark County. (2010). 20-Year comprehensive growth management plan, 2004-2024. Clark County, WA.

Collins, S. L., Carpernter, S. R., Swinton, S. M., Orenstein, D. E., Childers, D. L., Gragson, T. L., et al. (2011). An integrated conceptual framework for long-term social-ecological research. Frontiers in Ecology and the Environment, 9, 351-357.

Daniels, T. L., \& Nelson, A. C. (1986). Is Oregon's farmland preservation program working? Journal of the American Planning Association, 52(1), 22-32.

Dempsey, J. A., \& Plantinga, A. J. (2013). How well do urban growth boundaries contain development? Results for Oregon using a difference-in-difference estimator. Regional Science and Urban Economics, 43, 996-1007.

Furuseth, O. J. (1981). Update on Oregon's agricultural protection program: A land use perspective. Natural Resource Journal, 21(1), 57-70.

Gosnell, H., Kline, J. D., Chrosteg, G., \& Duncan, J. (2010). Is Oregon's Land Use Planning Program conserving forest and farm land? A review of the evidence. Land Use Policy, 28(1), 185-192.

Gray, A. N., Azuma, D. L., Lettman, G. J., Thompson, J. L., \& McKay, N. (2013). Changes in land use and housing on resource lands in Washington State, 1976-2006. Gen. Tech. Rep. PNW-GTR-881. Portland, OR: U.S. Department of Agriculture, Forest Service, Pacific Northwest Research Station.

Gustafson, G. C., Daniels, T. L., \& Shirack, R. P. (1982). The Oregon land use act: Implications for farmland and open space protection. Journal of the American Planning Association, 48(3), 365-373.

Harvey, T., \& Works, M. A. (2002). Urban sprawl and rural landscapes: Perceptions of landscape as amenity in Portland, Oregon. Local Environment: The International Journal of Justice and Sustainability, 7(4), 381-396.

Jun, M. (2004). The effects of Portland's urban growth boundary on urban development patterns and commuting. Urban Studies, 41(7), 1333-1348.

Kline, J. D. (2000). Comparing states with and without growth management: Analysis based on indicators with policy implications comment. Land Use Policy, 17. 349-355.

Kline, J. D. (2005). Forest and farmland conservation effects of Oregon's (USA) land use planning program. Environmental Management, 35(4), 368-380.

Kline, J. D., \& Alig, R. J. (1999). Does land use planning slow the conversion of fores and farmlands? Growth and Change, 30, 3-22.

Kline, J. D., Azuma, D. L., \& Moses, A. (2003). Modeling the spatially dynamic distribution of humans in the Oregon (USA) Coast Range. Landscape Ecology, 18(4), 347-361.

Kline, J. D., Moses, A., Azuma, D. L., \& Gray, A. (2009). Evaluating satellite imagery-based land use data for describing forest land development in western Washington. Western Journal of Applied Forestry, 24(4), 214-222.

Knaap, G. (1994). Land use politics in Oregon. In C. Abbott, D. Howe, \& S. Adler (Eds.), Planning the Oregon way (pp. 3-23). Corvallis, OR: Oregon State University Press.
Knaap, G. \& Nelson, A. C. (1992). The regulated landscape: Lessons on state land use planning from Oregon. Cambridge, MA: Lincoln Institute of Land Policy.

Lettman, G. J. (2011). Forest, farms, and people: Land use change on non-federal land in Oregon, 1973-2009. Salem, OR: Oregon Department of Forestry.

Lettman, G. J. (2013). Land use change on non-federal land in Oregon and Washington. Salem, OR: Oregon Department of Forestry. http://www.oregon.gov/odf/ RESOURCE_PLANNING/docs/land use in_OR_WA web_edited.pdf

Lucas v. South Carolina Coastal Council, 505 U.S. 1003. (1992).

Nelson, A. C. (1992). Preserving prime farmland in the face of urbanization: Lessons from Oregon. Journal of the American Planning Association, 58(4), 467-488.

Nelson, A. C. (1999). Comparing states with and without growth management: Analysis based on indicators with policy implications. Land Use Policy, 16, $121-127$.

Nelson, A. C., \& Moore, T. (1996). Assessing growth management policy implementation: Case study of the United States' leading growth management state. Land Use Policy, 13(4), 241-259.

Ozawa, C. P. (2012). Creating livable cities: The story of Portland, Oregon. In M. Agnoletti, A. Carandini, \& W. Santagata (Eds.), Essays and researches, international biennial of cultural and environmental heritage. Pisa, Italy: Bandecchi \& Vivaldi.

Ozawa, C. P., \& Yeakley, J. A. (2007). Performance of management strategies in the protection of riparian vegetation in three Oregon cities. Journal of Environmental Planning and Management, 50, 803-822.

Pease, J. R. (1994). Oregon rural land use: Policy and practices. In C. Abbott, D. Howe \& S. Adler (Eds.), Planning the Oregon way (pp. 163-188). Corvallis, OR: Oregon State University Press.

Rosan, C. (2007). Metropolitan governance and local land use planning in Boston, Denver, and Portland (Doctoral thesis). Cambridge, MA: Massachusetts Institute of Technology.

Seltzer, E. (2004). It's not an experiment: Regional planning at Metro, 1990 to the present. In C. P. Ozawa (Ed.), The Portland edge: Challenges and successes in growing communities (pp. 35-60). Washington, DC: Island Press.

Settle, R. L. \& Gavigan, C. G. (1993). The growth management revolution in Washington: Past, present, and future. University of Puget Sound Law Review, 16, 867-948

Sorensen, A. A., Greene, R. P., \& Russ, K. (1997). Farming on the edge. DeKalb, IL: American Farmland Trust, Center for Agriculture and the Environment, Northern Illinois University.

Stein, S. M., McRoberts, R. E., Alig, R. J., Nelson, M. D., Theobald, D. M., Eley, M. et al. (2005). Forests on the edge: Housing development on America's private forests. PNW-GTR-636. Portland, OR: U.S. Department of Agriculture, Forest Service.

Thiers, P., Stephan, M., \& Walker, A. (2011). Differences in regime and structure within an ecological region: Comparing environmental governance in the Portland-Vancouver metropolitan area. Presented paper: American Political Science Association Annual Meeting, September 1-4, Seattle, WA

US Department of Commerce, Census Bureau. (2000). State and county quick facts. Washington, DC: U.S. Department of Commerce. http://quickfacts. census.gov/qfd/index.html

Walker, A. P. (2011). Growth management in Clark County, 1990-2011 (Undergraduate thesis). Portland, OR: Reed College.

Wooldridge, J. M. (2006). Introductory econometrics. Mason, OH: Thomson SouthWestern.

Yeakley, J. A., Ozawa, C. P., Fisher de Leon, A. D., \& Armstrong, C. M. (2012). Gains and losses of urban riparian greenspaces in Portland-Vancouver. In Proceedings of the AWRA 2012 summer specialty conference, riparian ecosystems IV: Advancing science, economics and policy (pp.17-21). Denver, CO: American Water Resources Association. 